\section{COVID-19 AND SURFING: PROBLEMS, STRATEGIES AND SOLUTIONS FOR SURFERS}

\author{
COVID-19NO SURFE: PROBLEMAS, ESTRATÉGIAS E SOLUÇÕES PARA OS ATLETAS DO SURFE \\ COVID-19 EN EL SURF:PROBLEMAS, ESTRATEGIAS Y SOLUCIONES PARA LOS ATLETAS DEL SURF
}

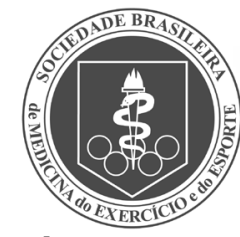

Artigo esPeCial

SPECIAL ARTICLE

ARticulo esPeCial

\begin{abstract}
Guilherme Henrique Vieira Lima'1,2 (Physician)

Pedro Luiz Guimarães ${ }^{3}$ (DD

(Physician)

Marcelo Baboghluian 4,5 (ID

(Physician)

1. Faculdade de Medicina do ABC, São Paulo, SP, Brazil.

2. Sociedade Brasileira Medicina do Exercício e do Esporte - SBMEE, São Paulo, SP, Brazil.

3. Universidade Federal do Rio de Janeiro, Rio de Janeiro, RJ, Brazil.

4. Faculdade de Medicina de

Taubaté, São Paulo, SP, Brazil.

5. Instituto Mar Azul de Medicina

Esportiva, São Paulo, SP, Brazil.
\end{abstract}

\section{Correspondence:}

Guilherme Vieira Lima. Rua Estela,

121, apto 141, Paraíso, São Paulo,

SP, Brazil. 04011-001.

guigavl@yahoo.com

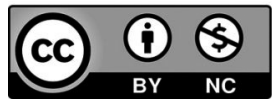

\begin{abstract}
The pandemic caused by coronavirus disease (COVID-19) has changed the routine of surfers, professionals and all those involved in surfing. This unusual global crisis has caused major organizational, financial and social disruption for surfers, coaches, federations and fans. The world of sports, including surfing, entered extreme and uncharted territory, in which all competitions were postponed and many beaches were closed, preventing any kind of surfing activity. The primary objective of this article is to identify potential harmful effects caused by the COVID-19 pandemic on the health of surfers, while the secondary objective is to provide practical recommendations for coaches, professional and amateur surfers to reduce the undesirable consequences of forced quarantine and direct the resumption of surfing activities while protecting the health of those involved. The main problems indicated were: the effects on body composition due to calorie imbalance, possible cardiac and pulmonary alterations caused by COVID-19, musculoskeletal symptoms and the consequences of detraining. The article also suggests recommendations for new attitudes towards surfing. Surfing is a growing sport that has been included in the upcoming Olympic Games in Tokyo. As the sport grows and becomes more professional, measures to protect the health of surfers need to be put in place. The current pandemic situation is extremely delicate and the measures proposed in this study are intended to serve as a guide for surfers and professionals in order to minimize the harmful effects of this situation. Level of Evidence IV; Type of Study: Literature review.
\end{abstract}

Keywords: Water sports; Coronavirus infections; Sports medicine; Pandemics.

\section{RESUMO}

A pandemia provocada pela doença do coronavírus (COVID-19) modificou a rotina dos praticantes, profissionais e todos envolvidos no surfe. Essa crise global incomum causou uma grande perturbação organizacional, financeira e social para atletas, treinadores, federações e torcedores. O mundo dos esportes, inclusive o surfe, entrou em uma situação extrema e desconhecida, na qual todas as competições foram adiadas e muitas praias foram fechadas, impedindo qualquer tipo de prática. O objetivo primário deste trabalho é identificar os possiveis efeitos deletérios provocados pela pandemia do COVID-19 sobre a saúde dos surfistas, e o secundário é fornecer recomendações práticas para treinadores, atletas e praticantes para reduzir as consequências indesejadas da quarenten a forçada e guiar r retorno às atividades esportivas de forma saudável. Os principais problemas apontados foram: os efeitos na composição corporal devido ao desequilíbrio calórico, possíveis alterações cardíacas e pulmonares provocadas pela COVID-19, sintomas osteomusculares e as consequências do destreinamento. O trabalho também sugere recomen dações de novas atitudes na prática do esporte. O surfeéuma modalidade esportiva em crescimento, que estará presente na próxima edição dos Jogos Olímpicos de Tóquio. À medida que o esporte se profissionaliza e cresce, as condutas de suporte de saúde dos praticantes fazem-se necessárias. O momento atual de pandemia é extremamente delicado e as medidas propostas neste estudo visam orientar os atletas e profissionais ligados a esta modalidade esportiva, com a finalidade de minimizar os efeitos deletérios deste momento. Nível de Evidência:IV; Tipo de Estudo: Revisão Sistemática.

Descritores: Esportes aquáticos; Infecções por coronavírus; Medicina esportiva; Pandemias.

\section{RESUMEN}

Lapandemia provocada por la enfermedad del coronavirus (COVID-19) modificóla rutina delos practicantes, profesionales y todos los involucrados en el surf. Esta crisis global inusual ocasionó una gran perturbación organizacional, financiera y social para atletas, entrenadores, federaciones y aficionados. El mundo de los deportes, inclusive el surf, entró en una situación extrema y desconocida, en la que todas las competiciones fueron postergadas y muchas playas fueron cerradas, impidiendo cualquier tipo de práctica. El objetivo primario de este trabajo es identificar los posibles efectos deletéreos provocados por la pandemia de COVID-19 sobre la salud de los surfistas, y el secundario es suministrar recomendaciones prácticas para entrenadores, atletas y practicantes para reducir las consecuencias indeseadas de la cuarentena forzada y guiar el retorno a las actividades deportivas de forma saludable. Los principales problemas apuntados fueron: Ios efectos en la composición corporal debido al desequilibrio calórico, posibles alteraciones cardíacas y pulmonares provocadas por la COVID-19, síntomas osteomuscularesy las consecuencias del desentrenamiento. El trabajo también sugiere recomendaciones de nuevas actitudes en la práctica del deporte. El surf es una modalidad deportiva en crecimiento, que estará presente en la próxima edición de 
los Juegos Olímpicos de Tokio. A medida que el deporte se profesionaliza y crece, las conductas de soporte de salud de los practicantes se hacen necesarias. El momento actual de pandemia es extremamente delicado y las medidas propuestas en esteestudio buscan orientar a los atletas y profesionales vinculados a esta modalidad deportiva, con la finalidad de minimizar los efectos deletéreos de este momento. Nivel de Evidencia: IV; Tipo de Estudio: Revisión Sistemática.

Descriptores: Deportes acuáticos; Infecciones por coronavirus; Medicina deportiva; Pandemias.

\section{INTRODUCTION}

Coronavirus disease (COVID-19) was first identified in Wuhan, Hubei Province, People's Republic of China, in December 2019. On January 30, 2020, the World Health Organization (WHO) declared COVID-19 a Public Health Emergency of International Concern. Later on, due to the alarming levels of contamination and severity, WHO characterized COVID-19 as a pandemic. ' Since then, several measures have been implemented by governments seeking to contain the spread of the virus and reduce the number of cases. The measures with the greatest influence on surfing on all the beaches in the world are quarantine and social isolation.

This unusual global crisis has caused major organizational, financial and social disruption for surfers, coaches, federations and fans. The world of sports, ${ }^{2}$ including surfing, entered extreme and uncharted territory, in which all competitions were postponed and many beaches were closed, preventing any kind of surfing activity.

Regarding transmission among surfers, there is still widespread debate on the potential for infection through seawater, although there are not yet any studies confirming contamination by this route. In a study of 4382 articles of which 63 were selected for review, La Rosa et al. ${ }^{3}$ demonstrated that there is insufficient evidence that human coronaviruses are present in surface water and groundwater, or are transmitted through contaminated water. ${ }^{3}$ Studies covering the risk of frequenting beaches are related to airborne transmission by aerosols and transmission by contaminated objects. ${ }^{1,2,3}$

Major local and international competitions, such as the events of the WCT - World Championship Tour and WQS - World Qualifying Series, organized by the WSL - World Surf League, the top professional surfing organization, and even the Tokyo Olympic Games, have been postponed. ${ }^{4,5}$ Surfing competitions characteristically take place in different locations, which means surfers are obliged to visit different beaches and travel frequently. During a pandemic, this condition is unfeasible.

Surfers often experience periods of change in routine throughout their sports careers, usually due to problems such as illnesses, injuries or even breaks between seasons. However, this loss of physical activity is not comparable to the restriction imposed by the current confinement. Regardless of its duration, isolation has a significant impact on the physical and mental state of every athlete, and in the case of surfing, in which beach and waves are mandatory elements, the consequences are even greater.

The vast majority of professional surfers are young, healthy and not part of a high-risk group. A large number of surfers may have had an asymptomatic infection, yet after a long period of quarantine and social isolation, many individuals have experienced a reduction in their physical activity levels, developed poor dietary habits, and may even have been symptomatic carriers of COVID-19. In order to ensure the resumption of surfing in a healthy manner and minimize the chance of injury, it is very important that surfers and health professionals be aware of the impact that this pandemic and the isolation period may have caused on health.

Some cities and countries have started to show a reduction in the number of cases and begun to relax their social isolation rules, which enables many surfers to get back into the sport. The primary objective of this study is to identify the potential harmful effects caused by the COVID-19 pandemic on the health of professional surfers, while the secondary objective is to provide practical recommendations for coaches and surfers to reduce the undesirable consequences of forced quarantine and to direct the resumption of surfing activities while protecting the health of those involved.

\section{Effects on body composition}

Effects on body composition are mainly due to the imbalance between caloric intake and output caused by the change in the daily routine during quarantine. ${ }^{6}$

Regarding calorie intake, we observed a change in the dietary pattern caused by problems of different origins, such as: limited access to store and market services, poorer product selection, "overeating" and changes in eating habits. On the other hand, we noticed a significant decrease in energy expenditure due to a reduction in the surfers physical activity levels?

It is known that physical inactivity for more than three days associated with a lack of nutritional control can lead to a calorie imbalance, promoting an increase in fat mass and a decrease in lean mass. Weight gain resulting in increased fat and reduced muscle mass negatively alters the performance and metabolic capacity of the professional surfer. ${ }^{7,89}$

\section{Cardiac Effects}

The cardiovascular system is one of the main systems that can be compromised by the SARS-Cov-2 virus responsible for COVID-19. Causes include the harmful action of the virus on ACE2 receptors, present in the myocardium. In addition, coronavirus promotes a proinflammatory and prothrombotic state, which can trigger an acute coronary syndrome. ${ }^{10}$

Inflammation of the heart muscle, known as myocarditis, is a major cause of sudden death in individuals under 35-40 years of age. It can present a very wide range of heterogeneous symptoms, including nonspecific signs such as: fatigue, malaise, muscle pain, nausea and vomiting, and more specific signs such as: chest pain, palpitations, dyspnea, increased resting heart rate and reduced heart function with exercise intolerance. Myocarditis can also leave tissue scars responsible for dilated cardiomyopathy and arrhythmias. ${ }^{10,11}$

At the time of publication of this document, there is insufficient data to describe a typical cardiac presentation and long-term signs of myocarditis associated with COVID-19.

Professional surfers must pay close attention to any clinical sign as many of these nonspecific symptoms can be misinterpreted or confused with conditions directly related to training (e.g. burnout or overtraining syndrome, depression or psychosomatic disorders). ${ }^{10,11,12}$ In addition, most professional surfers do not meet the criteria of the high-risk group for this viral disease, and if infected are often asymptomatic; however, this fact does not rule out the risk of myocardial impairment. ${ }^{11,12}$

Thus, it is recommended that all professional surfers who have been contaminated by the SARS-CoV-2 virus should undergo a cardiac assessment for risk stratification before resuming surfing ${ }^{11,12}$ activities. The basic suggestion for initial management of the resumption of surfing activities following COVID-19 quarantine is illustrated in the flowchart in Figure 1. 


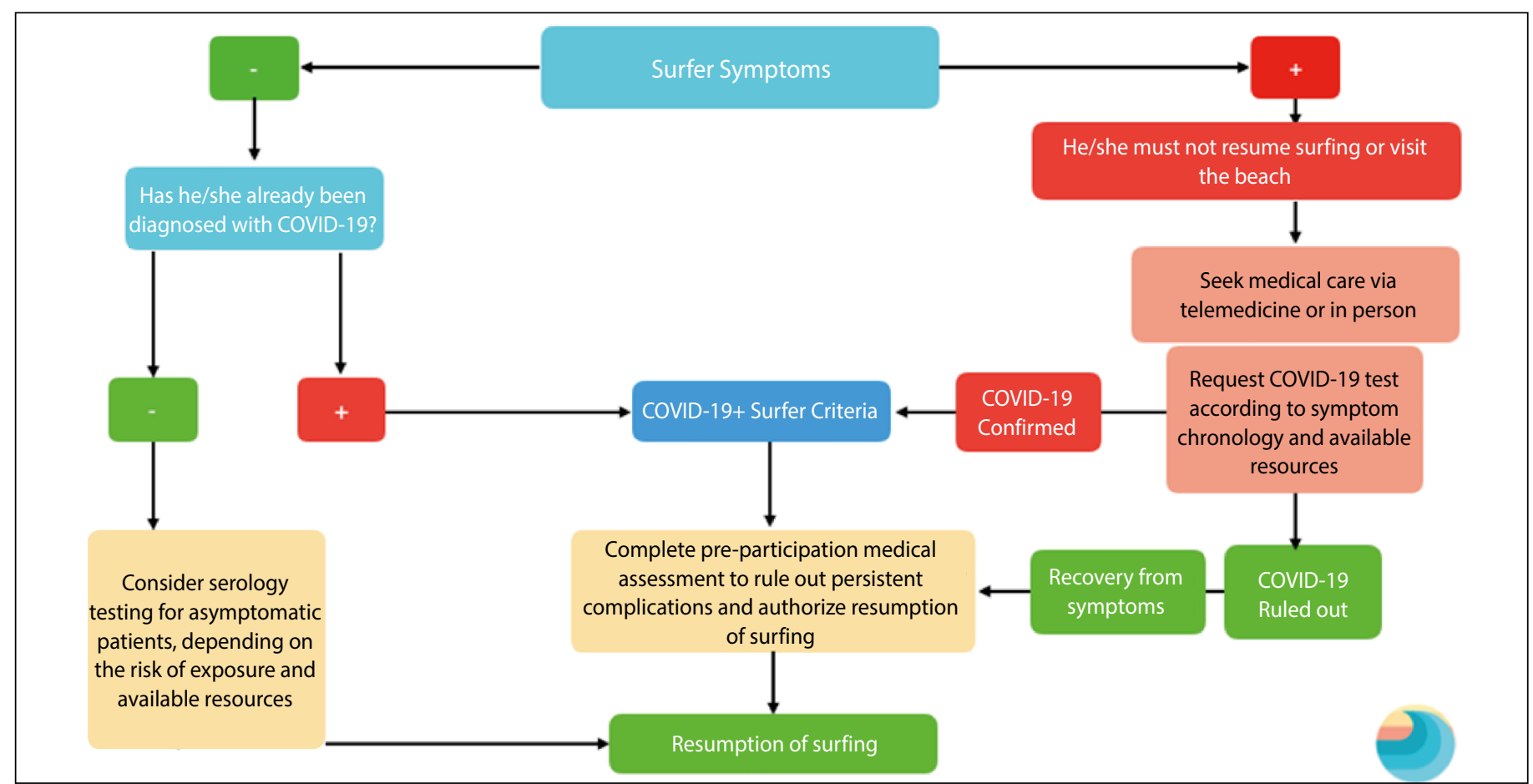

Figure 1. Initial management plan for resumption of surfing after quarantine.

\section{Pulmonary Effects}

The inflammatory response of the lung caused by coronavirus infection can trigger severe acute respiratory syndrome (SARS-CoV-2) and manifest important respiratory symptoms such as dyspnea, tiredness, chest pain and cough, which can progress to acute respiratory distress syndrome (ARDS), with a much more severe clinical presentation. ${ }^{13}$

SARS caused by coronavirus is a syndrome that can cause long-term damage to the lungs. A number of individuals may present with respiratory function abnormalities with a mild to moderate restrictive pattern, even after the remission of symptoms. Some studies with other coronavirus subtypes show a rate of $6 \%$ to $20 \%$ of subjects presenting with this alteration for up to six to eight weeks after hospital discharge. ${ }^{14,15}$ Moreover, Hui D et al. demonstrated a reduction in exercise capacity for up to one year after contamination with the virus. ${ }^{16}$

Pulmonary rehabilitation with exercise training, education and behavioral modification designed to improve physical fitness is recommended for individuals infected by COVID-19 with respiratory repercussions. ${ }^{17}$ The program reduces symptoms, and increases functional capacity even in those with irreversible changes in lung architecture. ${ }^{18}$ The objectives of this rehabilitation are to improve functional exercise capacity and quality of life, reduce the sensations of dyspnea and allow the resumption of competitive professional physical activity. ${ }^{17}$

Due to the high demands of aerobic exercise on the lungs of professional surfers interspersed with periods of transient apnea, ${ }^{19}$ an ergospirometric test is recommended to prescribe individual thresholds and workloads, along with an assessment to be carried out by a specialized pulmonologist before resuming activities at sea. ${ }^{17}$

\section{Musculoskeletal Effects}

Musculoskeletal symptoms such as fatigue, myalgia and arthralgia are common findings of COVID-19, and are usually present in the initial stage of the disease, although there are reports of symptoms lasting until the final stage. ${ }^{20,21}$

The prevalence of fatigue ranges from $25.6 \%$ to $50 \%$ of cases, whereas arthralgia and myalgia range from $15.5 \%$ and some studies report incidences greater than 50\%. The wide variation in incidence is due to the broad spectrum of manifestation of the virus. Moreover, there is also a disparate pattern of musculoskeletal impairment between different population groups. Chinese studies show lower rates than in Europe, but there is no justification for this difference at the present time.22

If a surfer's quality of life deteriorates significantly because of these symptoms, it is recommended that he/she seek medical attention. This is necessary since, in these cases, the clinical characteristics of these symptoms must be analyzed considering the new inflammatory evidence in COVID-19. Musculoskeletal symptoms should be analyzed together with laboratory findings, such as inflammatory and infection-related parameters (interleukin-6, procalcitonin, C-reactive protein). ${ }^{22}$

The involvement of the musculoskeletal system has not been thoroughly investigated during this pandemic. To date, there are no published studies or scientific articles on the presence of coronavirus in muscles, joints or bones. These symptoms are attributed only anecdotally as indirect effects, mainly resulting from the inflammatory and/or immune response to infection. Nevertheless, there are studies which uphold that other mechanisms may be associated, such as direct damage by the virus to the endothelium or peripheral nerves. We believe that shedding light on the real mechanism involved with these symptoms can help us plan specific rehabilitation protocols in patients with COVID-19.22

Regardless of the surfer's skill levels, it is important to understand that quarantine and social isolation can represent a period of significant decrease in the volume and intensity of training, with drastic changes in a surfer's daily routine and sports activities. Therefore, the orthopedic impact on a surfer's resumption of normal activities should also be taken into account. Overtraining - defined as prolonged or excessive repetitive activity/exercises - as an option to "catch up" does not allow the body to adjust and recover, which can lead to diminished performance and/or an increased risk of injuries.

\section{Resumption of surfing activities after confirmed COVID-19}

Prior to the start of this study, we did not find any protocols on the resumption of physical activities based on the duration of coronavirus infection in the literature studied. As reported in the cited sections of this study, the criteria used are mostly clinical, symptomatic, and sometimes obtained through subsidiary tests. 
In order to avoid an unnecessary extension of the isolation period for surfers with COVID-19 and to minimize the deleterious effects of this period of withdrawal from physical activities, we used the ANVISA ${ }^{23}$ (Brazilian National Health Surveillance Agency) protocol updated according to the US CDCs ${ }^{24}$ (Centers for Disease Control and Prevention) to release patients from isolation in a safe and non-contagious manner. The following items are considered in this protocol: presence and intensity of symptoms, the patient's immune status, timing of the first positive RT-PCR test and febrile state over a period of less than 24 hours (without the use of antipyretic drugs). If the individual has a fever, he or she must continue to self-isolate taking all the necessary measures to avoid transmission.

The strategy for release from isolation is illustrated in the diagram in Figure 2 below:

\section{Effects of "Detraining" \\ Concept}

Complete or partial loss of training-induced adaptation. The various physiological systems are affected and their corresponding physical capacities such as strength, power, endurance, speed and flexibility are impaired. ${ }^{25}$ Studies show that a short period of two to four weeks of detraining is already sufficient to compromise the gains, leading to a return to baseline values. ${ }^{25}$

\section{Deleterious Effects}

Loss of cardiovascular capacity and metabolic potential generates widespread deficits in aerobic exercise performance. ${ }^{26}$ The main effects are: (1) a rapid initial decline in VO2max; (2) decrease in blood volume; (3) changes in cardiac hypertrophy; (4) decrease in the total hemoglobin content; (5) decrease in skeletal muscle capillarization; and (6) disruption in thermoregulation. When this period extends beyond four weeks, the effects became more severe, such as: (1) additional reductions in VO2max; (2) reductions in the maximal arteriovenous oxygen difference; (3) changes in the maximal oxygen supply, which can result from reductions in the total hemoglobin content and/or in the maximal muscle blood flow and in vascular conductance; (4) decline in skeletal muscle oxidative enzyme activity; and (5) reductions in submaximal exercise performance, which may be related to changes in the mean transit time of the blood flow through the active muscle and/or in the thermoregulatory response to exercise. ${ }^{27}$
Reduced or complete absence of strength training can also cause loss of muscle mass. When inactivity exceeds four weeks, there is a fast-to-slow muscle fiber transition. ${ }^{28}$ In the short term it affects the eccentric strength and the size of type II fast-twitch muscle fibers. ${ }^{29}$ Neufer et al. ${ }^{26}$ noted that a decrease in fast-switch muscle fiber caused a decrease in the capacity to apply force to move through the water in swimmers, which may possibly affect paddling in surfers.

The ability to move a joint without restriction or pain depends on the condition of different structures, such as bone, muscle and connective tissue. Periods of prolonged inactivity can promote shortening, hypertonia or hypotonia of different muscle groups, in addition to capsular ligament stiffness or laxity. These imbalances can denote the onset of joint pathologies. ${ }^{30}$

\section{Guidelines for minimizing effects}

Strength exercises such as running on a treadmill or cycling on a stationary exercise bike should be incorporated into the routine of surfers so as to minimize the effects of metabolic potential. $., 26,27$

Loturco et al. ${ }^{31}$ demonstrated the importance of plyometric training in order to avoid damage such as muscle stretching. This simple advice can help maintain/improve all neuromuscular indices relevant to athletic performance and can form the basis of an ideal detraining strategy. ${ }^{31}$ In addition, exercises to maintain joint flexibility and eccentric muscle activation $^{32}$ are very important for activities that involve explosive muscle strength such as surfing.

\section{New sport etiquette}

The stage of the COVID-19 pandemic differs greatly between each town or city, state and country. For this reason, there are places where surfing is allowed, while in others it is temporarily prohibited. Therefore, establishing a pattern of new surfing etiquette is very important to standardize the attitudes of all surfers. Based on the recommendations of the Ministry of Health ${ }^{33}$ and the Brazilian Surfing Confederation, ${ }^{34}$ this study recommends:

a. Pre-surf (before arriving at the beach):

- Pay attention to the laws, prohibitions and authorizations in force in your town or city;

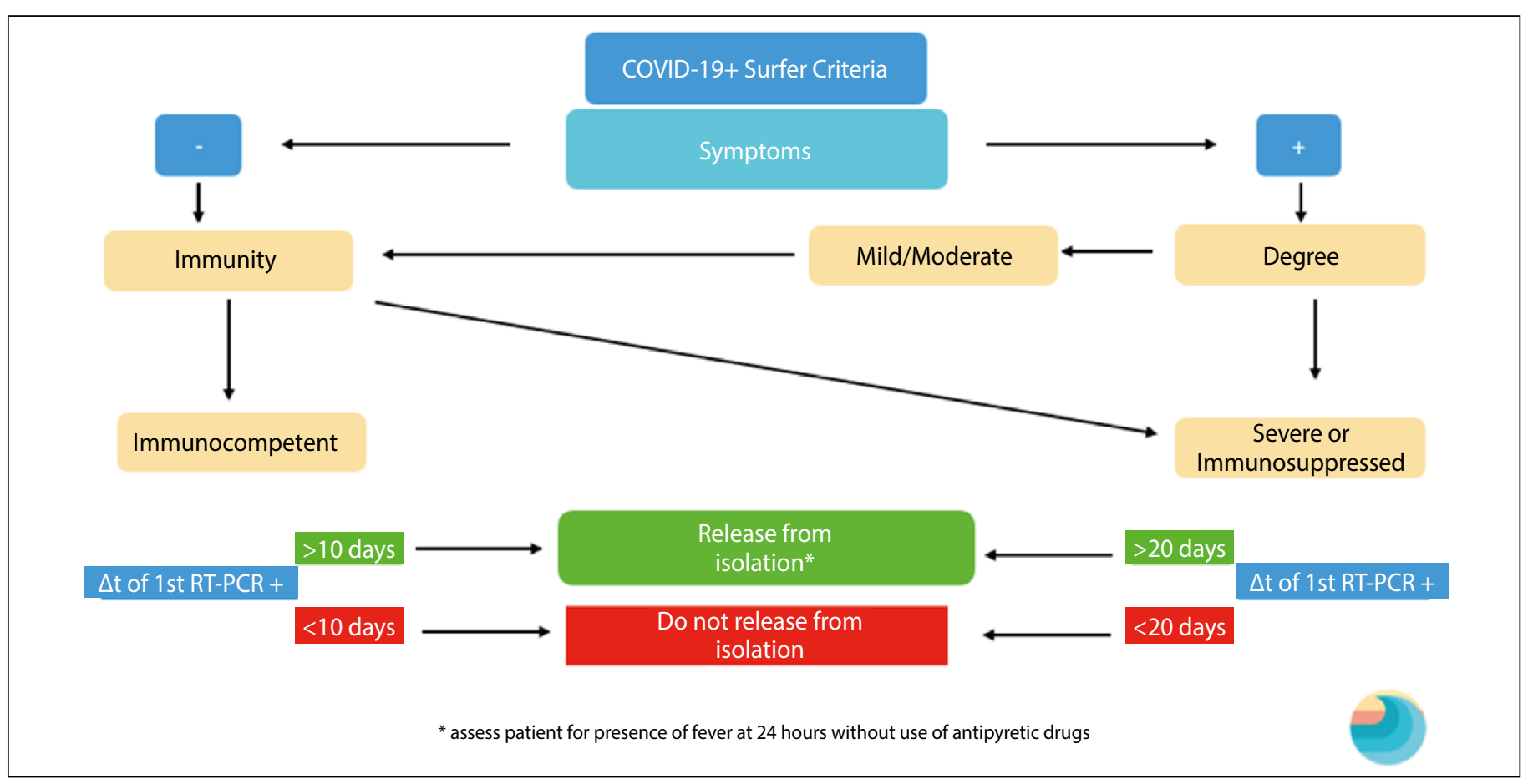

Figure 2. Criteria for release from isolation of surfers testing positive for COVID-19. 
- If you are experiencing any symptoms related to COVID-19, self-isolate at home

- Avoid going surfing at beaches other than the one closest to your home or the beach you normally frequent;

- Avoid the use of public transport. If you have to travel by public transport, respect the rules on face coverings and wash your hands as soon as possible with soap and water or $70 \%$ alcohol hand sanitizer gel;

- Avoid sharing modes of transport such as motorcycles and cars;

- Wear your mask all the way to the beach;

- Arrive at the beach dressed and ready to surf;

- Perform warm-up exercises before arriving at the beach;

- Do not touch your eyes and mouth with your hands before cleaning your hands.

b. Intra-surf (upon arriving at the beach, during the session, when leaving the sea):

- Maintain social distancing (at least two meters away from others) at all times;

- Greetings and salutations without physical contact;

- Store your mask in a plastic bag on the beach and keep it dry at all times. Do not enter the water wearing or carrying your mask;

- Before replacing your mask after surfing, dry your hands and face well in order to keep the mask dry at all times;

- Keep surf sessions short (avoid staying more than one hour);

- Do not share objects such as: surfboard wax, boards and other utensils;
- Each surfer is responsible for cleaning his or her own equipment; - If surf conditions are not ideal; avoid surfing, do not risk exposure for no reason;

c. Post-Surf (when leaving the beach and on your trip home):

- Do not stay on the beach after your session, go straight home;

- Do not share towels and/or clothing;

- Do not use public showers;

- Wear a mask throughout your return journey;

- Always wash your hands with soap and water or 70\% alcohol hand sanitizer gel; upon arriving home avoid touching your mucous membranes (mouth and eyes) with your hands before washing your hands; - The surfer himself/herself must clean all of his/her equipment and utensils that have been exposed with soap and water or $70 \%$ alcohol.

\section{CONCLUSIONS}

Surfing is growing in popularity and will be present at the upcoming Tokyo Olympics. As the sport grows and becomes more professional, measures to protect the health of surfers need to be put in place. The current pandemic situation is extremely delicate and the measures proposed in this study are intended to serve as a guide for surfers and professionals involved in this sport in order to minimize the harmful effects of this situation.

$\overline{\text { All authors declare no potential conflict of interest related to this article }}$

AUTHORS' CONTRIBUTIONS: Each author made significant individual contributions to this manuscript. GVL: substantial contribution in the conception and design of the work, writing and critical review of the content, and final approval of the version of the article to be published. PLG: substantial contribution in the conception and design of the work, writing and critical review of the content, and final approval of the version of the article to be published; MB: writing and critical review of the content, and final approval of the version of the article to be published.

\section{REFERENCES}

1. Zu ZY, Jiang MD, Xu PP, Chen W, Ni QQ, Lu GM, Zhang LJ. Coronavirus Disease 2019 (COVID-19): A Perspective from China. Radiology. 2020;296(2):E15-25.

2. World Health Organization. Situation Report 65. 2020 [Acesso em 24 abr. 2020]. Disponível em: https://www.who.int/docs/default- source/coronaviruse/situation-reports/20200325-sitrep-65-covid-19.pdf?sfvrsn=2b74edd8_2

3. La Rosa G, Bonadonna L, Lucentini L, Kenmoe S, Suffredini E. Coronavirus in water environments: occurrence, persistence and concentration methods - a scoping review. Water Res. 2020;179:115899.

4. World Surf League. 2020 men's championship tour event schedule. 2020 [Acesso em??]. Disponível em: https://www.worldsurfleague.com/events/2020/mct

5. International Surfing Association. 2020 [Acesso em??]. Disponível em: https://www.isasurf.org

6. FitBit Staff. The impact of coronavirus on global activity. 2020 [Acesso em:]. Disponível em: https:// blog.fitbit.com/covid-19-global-activity/

7. Peçanha T, Goessler KF, Roschel H, Gualano B. Social isolation during the COVID-19 pandemic can increase physical inactivity and the global burden of cardiovascular disease. Am J Physiol Heart Circ Physiol. 2020;318(6):H1441-6.

8. Martinez-Ferran M, Guía-Galipienso F, Sanchis-Gomar F, Pareja-Galeano H. Metabolic Impacts of Confinement during the COVID-19 Pandemic Due to Modified Diet and Physical Activity Habits. Nutrients. 2020;12(6):1549.

9. Lee IM, Shiroma EJ, Lobelo F, Puska P, Blair SN, Katzmarzyk PT. Lancet Physical Activity Series Working Group. Effect of physical inactivity on major non-communicable diseases worldwide: an analysis of burden of disease and life expectancy. Lancet. 2012;380:219-29.

10. Luetkens JA, Isaak A, Zimmer S, Nattermann J, Sprinkart AM, Boesecke C, et al. Diffuse Myocardial Inflammation in COVID-19 Associated Myocarditis Detected by Multiparametric Cardiac Magnetic Resonance Imaging. Circ Cardiovasc Imaging. 2020;13(5):e010897.

11. Kochi AN, Tagliari AP, Forleo GB, Fassini GM, Tondo C. Cardiac and arrhythmic complications in patients with COVID-19. J Cardiovasc Electrophysiol. 2020;31(5):1003- 8.

12. Schellhorn P, Klingel K, Burgstahler C. Return to sports after COVID-19 infection: Do we have to worry about myocarditis? Eur Heart J. 2020:ehaa448.

13. Lee N, Hui D, Wu A, Chan P, Cameron P, Joynt GM, et al. A major outbreak of severe acute respiratory syndrome in Hong Kong. N Engl J Med. 2003;348(20):1986-94.

14. Chan KS, Zheng JP, Mok YW, Li YM, Liu YN, Chu MC, et al. Sars: prognosis, outcome and sequelae. Respirology. 2003;8 Suppl(Suppl 1):S36-40.

15. Ong KC, Ng AWK, Lee LSU, Kaw G, Kwek SK, Leow MKS, et al. 1-Year pulmonary function and health status in survivors of severe acute respiratory syndrome. Chest. 2005;128(3):1393-400.

16. Hui DS, Wong KT, Ko FW, Tam LS, Chan DP, Woo J, et al. The 1-year impact of severe acute respiratory syndrome on pulmonary function, exercise capacity, and quality of life in a cohort of survivors. Chest. 2005;128(4):2247-61.

17. Spruit MA, Singh SJ, Garvey C, ZuWallack R, Nici L, Rochester C, et al. An oficial American thoracic Society/ European respiratory Society statement: key concepts and advances in pulmonary rehabilitation. Am J Respir Crit Care Med. 2013;188(8):e13-64.

18. Liu K, Zhang W, Yang Y, Zhang J, Li Y, Chen Y, et al. Respiratory rehabilitation in elderly patients with COVID-19: a randomized controlled study. Complement Ther Clin Pract. 2020;39:101166.
19. Farley O, Harris NK, Kilding AE. Anaerobic and aerobic fitness profiling of competitive surfers. J. Strength Cond Res. 2012;26(8):2243-8

20. Pung R, Chiew CJ, Young BE, Chin S, Chen MIC, Clapham HE, et al. Investigation of three clusters of COVID- 19 in Singapore: implications for surveillance and response measures. Lancet 2020;395(10229):1039-46.

21. Godaert L, Proye E, Demoustier-Tampere D, Coulibaly PS, Hequet F, Dramé M. Clinical characteristics of older patients: the experience of a geriatric short-stay unit dedicated to patients with COVID-19 in France. J Infect. 2020;81(1):e93-4.

22. Cipollaro L, Giordano L, Padulo J, Oliva F, Maffulli N. Musculoskeletal symptoms in SARS-CoV-2 (COVID-19) patients. J Orthop Surg Res. 2020;15:178.

23. Anvisa. Nota técnica GVIMS/GGTES/ANVISA No 07/2020- Orientações para prevenção e vigilância epidemiológica das infecções por SARS-CoV-2 (COVID-19) dentro dos serviços de saúde. 2020 [Acesso em 05 ago. 2020]. Disponível em: http://portal.anvisa.gov.br/documents/33852/271858/ NOTA+TÉCNICA+-GIMS-GGTES-ANVISA+Nº+07-2020/f487f506-1eba-451f-bccd-06b8f 1 b0fed 6

24. Centers for Diseases Control. Duration of Isolation and Precautions for Adults with COVID-19. 2020 [Acesso em:??]. Disponível em: https://www.cdc.gov/coronavirus/2019-ncov/hcp/duration-isolation.html

25. Martínez-Muñoz FJ, Rubio-Arias JA, Ramos-Campo D, Alcaraz PE. Effectiveness of Resistance Circuit-Based Training for Maximum Oxygen Uptake and Upper-Body One-Repetition Maximum Improvements: A Systematic Review and Meta-Analysis. Sports Med. 2017;47(12):2553-68.

26. Neufer PD, Costill DL, Fielding RA, Flynn MG, Kirwan JP. Effect of reduced training on muscular strength and endurance in competitive swimmers. Med Sci Sports Exerc. 1987;19(5):486-90.

27. Jukic I, Calleja-González J, Cos F. Multidisciplinary Digital Publishing Institute; 2020. Strategies and solutions for team sports athletes in isolation due to COVID-19. Multidisciplinary Digital Publishing Institute; 2020.

28. Wang Y, Pessin JE. Mechanisms for fiber-type specificity of skeletal muscle atrophy. Curr Opin Clin Nutr Metab Care. 2013;16(3):243-50.

29. Hortobágyi T, Houmard JA, Stevenson JR, Fraser DD, Johns RA, Israel RG. The effects of detraining on power athletes. Med Sci Sports Exerc. 1993;25(8):929-35

30. American College of Sports Medicine. Guidelines for Exercise Testing and Prescription. Philadelphia, PA: Lippincott Williams \& Wilkins; 2000.

31. Loturco I, Pereira LA, Kobal R, Martins H, Kitamura K, Cal Abad CC, et al. Effects of detraining on neuromuscular performance in a selected group of elite women pole-vaulters: A case study. J Sports Med Phys Fit. 2017;57(4):490-5

32. Colliander EB, Tesch PA. Effects of detraining following short term resistance training on eccentric and concentric muscle strength. Acta Physiol Scand. 1992;144(1):23-9.

33. Ministério da Saúde. Saúde anuncia orientações para evitar a disseminação do coronavirus. 2020 [Acesso em??]. Disponível em: https://www.saude.gov.br/noticias/agencia-saude/46540-saude-anuncia-orientacoes-para-evitar-a-disseminacao-do-coronavirus

34. Confederação Brasileira de Surfe. Protocolo Covid-19 de segurança asnitária para a prática de surfe. 2020 [Acesso em??]. Disponível em: https://cbsurf.org.br/ protocolo-covid-19-de-segurança-sanitaria-para-a-pratica-de-surfe/ 